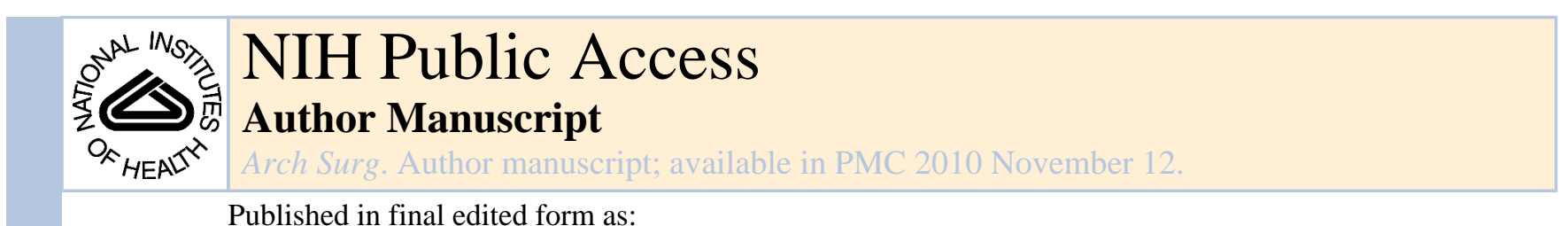

Published in final edited form as:

Arch Surg. 1971 August ; 103(2): 283-289.

\title{
Goodpasture's Syndrome:
}

\section{Treatment With Nephrectomy and Renal Transplantation}

Charles G. Halgrimson, MD, Curtis B. Wilson, MD, Frank J. Dixon, MD, Israel Penn, MD, James T. Anderson, MD, David A. Ogden, MD, and Thomas E. StarzI, MD, PhD Department of Surgery, Veterans Administration Hospital and University of Colorado School of Medicine, Denver, Department of Experimental Pathology, Scripps Clinic and Research Foundation, La Jolla, Calif

\section{Abstract}

Three young male patients developed acute glomerulonephritis and serious hemoptysis. All three had evidence of antiglomerular basement membrane (anti-GBM) antibodies in their serum and native kidneys. The pulmonary hemorrhages ceased after bilateral nephrectomy and splenectomy accompanied by irregular treatment with steroids and other immunosuppressants. Renal homotransplantation was successfully carried out from 95 to 162 days later, after circulating antiGBM antibodies had disappeared. Two of the homografts were biopsied and the third was removed 20,34 , and 2 months posttransplantation, respectively, and contained little or no immunoglobulin. Therefore, Good-pasture's syndrome does not contraindicate renal transplantation under the stipulated conditions of staged therapy.

Antibodies detectable by immunofluorescence and by elution react with the glomerular basement membrane producing glomerular injury. ${ }^{1-8}$ The subsequent glomerulonephritis often progresses rapidly and, when associated with pulmonary hemorrhage (sometimes fatal), is properly termed Goodpasture's syndrome. ${ }^{9-11}$ The pulmonary manifestations are presumed to involve cross reaction of the antiglomerular basement membrane (anti-GBM) antibodies with the alveolar septal basement membrane. ${ }^{1,3-5,8,12-25}$ In patients, many of whom were diagnosed on clinical grounds only, chronic systemic steroid therapy, other immunosuppressive agents, and hemodialysis have been inconsistent or valueless in controlling either these renal or pulmonary symptoms. ${ }^{11,16-22}$

This paper reports three patients with anti-GBM antibody mediated glomerulonephritis and pulmonary hemorrhage treated initially with splenectomy and bilateral nephrectomy 7 to 37 months ago. After circulating anti-GBM antibodies could no longer be detected, each patient received a renal homograft.

\section{Methods}

\section{General Care}

The surgical procedures and the general principles of postoperative care have been described elsewhere. ${ }^{23}$ Immunosuppression with azathioprine, prednisone, and equine antilymphocyte

Reprint requests to Department of Surgery, University of Colorado, 4200 E Ninth Ave, Denver 80220 (Dr. Halgrimson).

Read before the 28th annual meeting of the Central Surgical Association, Minneapolis, March 5, 1971.

Nonproprietary and Trade Names of Drugs

Azathioprine-Imuran.

Furosemide-Lasix. 
globulin (ALG) ${ }^{24}$ was begun two to four days before transplantation. The subsequent timing and dosage of the individual agents are shown in Fig 1 to 3. The recipients' ages, the timing of surgical interventions, and the source and match of kidney homografts are shown in the Table.

\section{Detection of Renal Bound and Circulating Anti-GBM Antibodies}

Snap frozen renal nephrectomized and biopsied specimens were examined for glomerularbound human immunoglobulins (IgG, $\operatorname{IgA}$, and $\operatorname{IgM}$ ), complement (C3), fibrin, albumin, and equine immunoglobulin by direct immunofluorescence. ${ }^{25}$ Anti-GBM antibodies eluted from this renal tissue with hypotonic citrate buffer ( $\mathrm{pH} 3.2)$ were detected by indirect immunofluorescence on normal human kidney sections. ${ }^{7,8}$ Circulating anti-GBM antibodies were sought by indirect immunofluorescence using normal human kidney sections. ${ }^{26}$ Preformed cytotoxic antibodies against donor lymphocytes were ruled out in all three cases by the direct cross-match method of Terasaki. ${ }^{27}$

\section{Report of Cases}

\section{Case 1}

A 30-year-old white man was admitted to the Denver Veterans Administration Hospital with a two-day history of hematuria. Within one week he developed hemoptysis, fluffy infiltrates throughout both lung fields, and oliguria $(250 \mathrm{ml} / 24 \mathrm{hr})$. A closed renal biopsy revealed necrotizing glomerulitis. Prednisolone (120 mg/day) did not halt progressive renal failure (Fig 1), necessitating hemodialysis; however, the lung fields cleared rapidly. He was treated with variable daily doses (usually $2 \mathrm{mg} / \mathrm{kg} /$ day) of mercaptopurine between the 11th and 30th days following admission. In January 1968, 115 days after the onset of symptoms, elective splenectomy and bilateral nephrectomy were performed. A severe, crescent-forming, subacute glomerulonephritis was present histologically (Fig 4). Anti-GBM antibodies were present in the kidneys and in the circulation. Renal homotransplantation followed after an additional 95 days when circulating anti-GBM antibodies had disappeared. There were no rejection episodes, and the normally functioning homograft was biopsied 34 months posttransplantation. No glomerular abnormalities were present by light microscopy (Fig 5).

\section{Case 2}

A 29-year-old white man had recurrent "bronchopneumonia" in September and October of 1968, associated with dyspnea and hemoptysis. On Jan 8, 1969, he was hospitalized in another city for these pulmonary symptoms and gross hematuria. Laboratory studies disclosed the following values: hematocrit reading, $20 \%$; blood urea nitrogen (BUN), $60 \mathrm{mg} / 100 \mathrm{ml}$; and antistreptolysin titer, 250 Todd units/100 ml (slightly elevated). Blood pressure was 160/80 $\mathrm{mm} \mathrm{Hg}$. Despite the maintenance of good urinary output, his BUN level rose to $152 \mathrm{mgl100}$ $\mathrm{ml}$.

On Jan 20, 1969, he was admitted to the Denver Veterans Administration Hospital in acute respiratory tract distress with muscle cramps, chills, tremor, and malaise. His blood pressure was $142 / 90 \mathrm{~mm} \mathrm{Hg}$ and he had 2+ pitting pretibial edema. His hematocrit reading was $25 \%$; BUN, $170 \mathrm{mg} / 100 \mathrm{ml}$; and serum creatinine, $9.5 \mathrm{mg} / 100 \mathrm{ml}$. Creatinine clearance was $5 \mathrm{ml} /$ min, and there was microscopic hematuria with $3+$ albuminuria. Anti-streptolysin titer was within normal limits; antinuclear antibody titers (ANA) and three LE preparations were negative. An x-ray film of the chest demonstrated bilateral interstitial infiltrates. On Jan 23 percutaneous renal biopsy revealed a severe, subacute, crescent-forming glomerulonephritis.

Treatment was started with $60 \mathrm{mg}$ of prednisone per day. Hemoptysis with inadequate oxygenation persisted, and on Feb 4, 1969, bilateral nephrectomy and splenectomy were 
carried out, even though significant renal function remained (serum creatinine, $13.5 \mathrm{mg} / 100$ $\mathrm{ml}$; creatinine clearance, $6 \mathrm{ml} / \mathrm{min}, \mathrm{BUN}, 146 \mathrm{mg} / 100 \mathrm{ml}$; and daily urine volume of about 900 $\mathrm{ml}$ ). The renal biopsy findings were confirmed (Fig 4) with anti-GBM antibodies detected in the nephrectomized kidneys and in the circulation (Fig 6 to 8).

After surgery, hemodialysis was started and repeated three times a week, while the steroid dosage was gradually lowered. Hemoptysis recurred (Fig 2 and 9) with near death from an alveolocapillary diffusion defect. The pulmonary hemorrhage ceased with increased dosage of prednisone which was subsequently tapered from 105 to $10 \mathrm{mg} /$ day. On July 3, 1969, a total of 149 days after nephrectomy and splenectomy, after the circulating anti-GBM antibodies had disappeared, he received a renal homograft from his brother, which has functioned normally since (Fig 2). He had serum hepatitis, Au-positive, in the early posttransplantation period. The homograft was biopsied 20 months after transplantation and no glomerular abnormalities were found by light microscopy (Fig 5).

\section{Case 3}

A 35-year-old white man noted anorexia and vomiting as well as ankle edema in late May 1970. One week later, intermittent hemoptysis began with no other pulmonary symptoms. His local physician observed gross hematuria. Laboratory studies revealed the following values: blood pressure, 150/100 mm Hg; anemia with a hematocrit reading of 33\%; BUN, $41 \mathrm{mg} / 100$ $\mathrm{ml}$; and serum creatinine, $3.1 \mathrm{mg} / 100 \mathrm{ml}$. Urinalysis showed 4+ protein, numerous granular casts, and gross blood. An x-ray film of the chest was normal except for prominent bronchovascular marking of the hilum of the left lung.

He was admitted to the Denver Veterans Administration Hospital on July 1, 1970. The previous laboratory and physical findings were confirmed except that the hematocrit reading had fallen to $25 \%$ and the BUN and serum creatinine had risen to $85 \mathrm{mg} / 100 \mathrm{ml}$ and $15.6 \mathrm{mg} / 100 \mathrm{ml}$, respectively. Rheumatoid factor, ANA, and three LE preparations were negative, and whole serum complement was normal. An X-ray film of the chest showed bilateral lower-lobe alveolar infiltrates. A needle biopsy of the kidney revealed acute glomerulonephritis with crescent formation.

Systemic heparinization and furosemide therapy were begun on July 3, 1970. Within three days he became oliguric and had severe hemoptysis and dyspnea (oxygen pressure $\left[\mathrm{Po}_{2}\right], 53 \mathrm{~mm}$ $\mathrm{Hg}$, while receiving oxygen nasally, 4 liters/min). The alveolar infiltrates in both lung fields had extended. Intermittent hemodialysis was begun. With the presumptive diagnosis of Goodpasture's syndrome, azathioprine and prednisone therapy were started, provided no perceptable benefit, and were discontinued. After a complicated course during which emergency thoracentesis and periardiocentesis were required, splenectomy and bilateral nephrectomy were done on Aug 19, 1970. Severe, crescent-forming subacute glomerulonephritis was present (Fig 4). Linear immunofluorescent deposits of human IgG and $\mathrm{C} 3$ were detected in the nephrectomized kidneys, and anti-GEM antibodies were present in the circulation.

A maternal kidney was transplanted after 162 days during which circulating anti-GEM antibodies had disappeared. After 18 hours of brisk diuresis, an apparent accelerated rejection took place with oliguria and azotemia, but not proteinuria. Adequate renal function returned (Fig 3) after one posttransplantation dialysis. 


\section{Results}

\section{Renal Bound and Circulating Anti-GBM Antibodies}

All three cases had direct immunofluorescent evidence of anti-GBM antibodies in the native kidneys, with linear deposits of $\operatorname{IgG}$ and $\mathrm{C} 3$ bound to the glomerular basement membrane (Fig 7). No deposits of IgA, IgM, fibrin, or albumin were identified. The presence of anti-GBM antibodies reactive with Bowman's capsule and to a portion of the tubular basement membranes in addition to GBM was confirmed by elution studies in cases 1 and 2 (Fig 7). Unfortunately, tissue was not available for elution in case 3 .

Homograft biopsies at 34 months (case 1) and 20 months (case 2) did not contain unusual human IgG, IgA, IgM, fibrin, albumin, or equine immunoglobulin deposits. Moderate amounts of $\mathrm{C} 3$ were present in vessel walls, and trace amounts of irregular $\mathrm{C} 3$ deposits were seen in the mesangial stalk.

Circulating anti-GBM antibodies were present before or following nephrectomy, or both, in all three patients (Fig 8). In case 1, circulating anti-GBM antibodies were detected by both indirect immunofluorescence and by fixation to a normal infant kidney interposed in the patient's arteriovenous dialysis shunt 16 days following nephrectomy. The anti-GBM antibodies in the perfused kidney were detected by direct immunofluorescence and confirmed by elution studies. Anti-GBM antibodies absent prior to transplantation (95 to 162 days after bilateral nephrectomy) have not recurred.

\section{Comment}

Subsequent renal transplantation provided long-term success in two of these cases. Similar treatment has been reported associated with favorable results in five additional patients with clinical courses compatible with Goodpasture's syndrome. ${ }^{28-31}$ In view of the limited number of patients and the complex therapeutic measures involving surgery, anesthesia, dialysis, and intensive immunosuppression, it is difficult to determine definitely specific effects of any single measure. No doubt multiple factors influence most events, for example, the importance of pharmacologic immunosuppression is indicated by the exacerbation of hemoptysis following reduction in prednisone dose in two of our patients. The dramatic improvement of pulmonary disease following nephrectomy in two of our patients is by no means a consistent finding. Further, it is even impossible to establish whether disappearance of circulating antiGEM antibodies is an essential prerequisite for successful renal transplantation, but this certainly seems likely. ${ }^{7}$

There are a number of theoretical aspects of the surgery employed which led to its application and should be considered. At least three immunologic consequences of the surgery may have had beneficial effects. First, splenectomy may reduce antibody forming potential, thereby contributing to fall in anti-GEM antibodies. Second, nephrectomy by eliminating the GEM may be removing an antigenic stimulus. Third, nephrectomy by removing the normal route of excretion of non renal basement membrane antigens, which presumably are derived from turnover of basement membrane generally and which cross-react with glomerular basement membrane, might cause an increase in circulating basement membrane antigens which could combine with anti-GEM antibodies, thereby protecting the lungs. ${ }^{15,32}$ The postnephrectomy improvement of patients with little or no residual renal function could not be attributed to this third mechanism. Unfortunately, there is no available direct evidence to support any of these possibilities; however, de Oliveira et $\mathrm{al}^{33}$ observed in rats that prior termination of renal excretion greatly lessened the pneumotoxic effect of heterologous nephrotoxic sera. This might have resulted in part from increased circulating basement membrane antigens or from the antiinflammatory effects of uremia or both. At least two theoretical disadvantages associated with 
nephrectomy did not seem to be important in these patients. The removal of the GBM did not appear to terminate any significant protective immuno-absorbent action. The accumulation, if any, of nonrenal basement membrane antigens in the circulation did not appear to serve as an immunogenic stimulus.

In the absence of more decisive evidence, we have adopted the following policies.

Nephrectomy and splenectomy are performed following stabilization of the clinical course with dialysis and steroid therapy. Circulating anti-GBM antibodies are monitored.

Immunosuppression is not provided during the waiting period unless circulating anti-GBM antibodies persist or pulmonary hemorrhage recurs. When circulating anti-GBM antibodies disappear, usually within six months, renal transplantation may proceed. If circulating antiGBM antibody remains, chronic immunosuppression should be considered.

Subsequent to the preparation of this paper, the patient in case 3 developed a staphylococcal wound abscess and severe bilateral bronchial pneumonia which led to his death 69 days following transplantation. Prior to death, immunosuppressive therapy was withdrawn and his kidney was removed after being in residence for 62 days. Postmorten examination revealed necrosis and abscess formation in both lungs due to infection with multiple organisms, including Pseudomonas aeruginosa, C albicans, Aspergillus, and cytomegalovirus. Histologic examination of the excised homograft revealed scant focal interstitial mononuclear cell accumulation. Focal glomerular hypercellularity was present with some cells containing intranuclear inclusion bodies. No conclusive evidence of anti-GBM antibodies in the homograft was found by immunofluorescence and acid elution studies of the $50 \mathrm{gm}$ of tissue available for study.

\section{Acknowledgments}

This investigation was supported by Public Health Service research grants A1-04152, Al-07007, A1-AM-08898, AM-12148, AM-06344, AM-07772, RR-00051, RR-00069, and HE-09110; Public Health Service contract PH-43-68-621; and Atomic Energy Commission contract AT (04-3) -410.

Elution studies on cases 1 and 2 were performed by Richard A, Lerner, MD, and John J. McPhaul, Jr., MD, respectively.

\section{References}

1. Sheer RL, Grossman MA. Immune aspects of the glomerulonephritis associated with pulmonary hemorrhage. Ann Intern Med 1964;60:1009-1021.

2. Duncan DA, Drummond KN, Michael AF, et al. Pulmonary hemorrhage and glomerulonephritis: Report of six cases and study of the renal lesion by fluorescent antibody technique and electron microscopy. Ann Intern Med 1965;62:920-938. [PubMed: 14283390]

3. Sturgill BC, Westervelt FB. Immunofluorescence studies in a case of Goodpasture's syndrome. JAMA 1965;194:914-918. [PubMed: 4158737]

4. Markowitz AS, Battifora HA, Schwartz F, et al. Immunological aspects of Goodpasture's syndrome. Clin Exp Immun 1968;3:585-591. [PubMed: 4178233]

5. Beirne GJ, Octaviano GN, Kopp WL, et al. Immunohistology of the lung in Goodpasture's syndrome. Ann Intern Med 1968;69:1207-1212. [PubMed: 4177811]

6. Poskitt TR. Immunologic and electron microscopic studies in Goodpasture's syndrome. Amer J Med 1970;49:250-257. [PubMed: 4195172]

7. Lerner R, Glassock RJ, Dixon FJ. The role of anti-glomerular basement membrane antibody in the pathogenesis of human glomerulonephritis. J Exp Med 1967;126:989-1004. [PubMed: 4964566]

8. McPhaul JJ Jr, Dixon FJ. Characterization of human anti-glomerular basement membrane antibodies eluted from glomerulonephritic kidneys. J Clin Invest 1970;49:308-317. [PubMed: 4983662]

9. Goodpasture EW. The significance of certain pulmonary lesions in relation to the etiology of influenza. Amer J Med Sci 1919;158:863-870. 
10. Benoit FL, Rulon DB, Theil GB, et al. Goodpasture's syndrome: A clinicopathologic entity. Amer J Med 1964;37:424-444. [PubMed: 14209289]

11. Proskey AJ, Weatherbee L, Easterling RE, et al. Goodpasture's syndrome: A report of five cases and review of the literature. Amer J Med 1970;48:162-173. [PubMed: 5416259]

12. Steblay RW, Rudofsky U. Autoimmune glomerulonephritis induced in sheep by injections of human lung and Freund's adjuvant. Science 160:204-206. 968. [PubMed: 4868225]

13. Koffler D, Sandson J, Carr R, et al. Immunologic studies concerning the pulmonary lesions in Goodpasture's syndrome. Amer J Path 1969;54:293-305. [PubMed: 4179624]

14. Hagadorn JE, Vazquez JJ, Kinney TR. Immunopathologic studies of an experimental model resembling Goodpasture's syndrome. Amer J Path 1969;57:17-30. [PubMed: 5307566]

15. Willoughby WF, Dixon FJ. Experimental hemorrhagic pneumonitis produced by heterologous antilung antibody. Immun 1970;104:28-37.

16. Rusby NL, Wilson C. Lung purpura with nephritis. Quart J Med 1960;29:501-511. [PubMed: 13744765]

17. Fairley KF, Kincaid-Smith P. Goodpasture's syndrome. Brit Med J 1961;2:1646.

18. Johnson JR, McGovern VJ. Goodpasture's syndrome and Wegner's granulomatosis. Aust Ann Med 1962;11:250-259.

19. Lunberg GD. Goodpasture's syndrome: Glomerulonephritis with pulmonary hemorrhage. JAMA 1963;184:915-919.

20. Walker JM, Joekes AM. Survival after haemoptysis and nephritis. Lancet 1963;2:1199-1201. [PubMed: 14072942]

21. Holman RE, Hutt MP, Brittain RS, et al. Goodpasture's syndrome: Treatment failure with azathioprine. JAMA 1966;196:31-32. [PubMed: 5952183]

22. Freeman RM, Vertel RM, Easterling RE. Goodpasture's syndrome: Prolonged survival with chronic hemodialysis. Arch Intern Med 1966;117:643-647. [PubMed: 5935017]

23. Starzl, TE. Experience in Renal Transplantation. Philadelphia: WB Saunders Co; 1964.

24. Starzl, TE. Experience in Hepatic Tmnsplantation. Philadelphia: WB Saunders Co; 1969.

25. Wilson CB, Dixon FJ. Antigen quantitation in experimental immune complex glomerulonephritis. J Immnn 1970;105:279-290.

26. McPhaul JJ Jr, Dixon FJ. The presence of anti-glomerular basement membrane antibodies in peripheral blood. J Immun 1969;103:1168-1175. [PubMed: 4902893]

27. Patel R, Terasaki PI. Significance of the positive crossmatch test in kidney transplantation. New Eng J Med 1969;280:735-739. [PubMed: 4886455]

28. Cleveland AJ, Lee HM, Prout GR, et al. Preservation of the cadaver kidney for renal homotransplantation in man. Surg Gynec Obstet 1964;119:991-996. [PubMed: 14239300]

29. Maddock RK Jr, Stevens LE, Reemtsma K, et al. Goodpasture's syndrome: Cessation of pulmonary hemorrhage after bilateral nephrectomy. Ann Intern Med 1967;67:1258-1264. [PubMed: 6061940]

30. Shires DL, Pfaff WW, DeQuesada A, et al. Pulmonary hemorrhage and glomerulonephritis: Treatment of two cases by bilateral nephrectomy and renal transplantation. Arch Surg 1968;97:699-703. [PubMed: 4879284]

31. Siegel RR. The basis of pulmonary disease resolution after nephrectomy in Goodpasture's syndrome. Amer J Med Sci 1970;259:201-213. [PubMed: 4917973]

32. McPhaul JJ Jr, Dixon FJ. Immunoreactive basement membrane antigens in normal human urine and serum. J Exp Med 1969;130:1395-1409. [PubMed: 4982026]

33. de Oliveira HL, Laus-Filho JA, Sarti W. Prevention of acute immunological lung change by previously induced acute uremia in rats. Int Arch Allerg 1966;29:384-392. [PubMed: 5934924] 


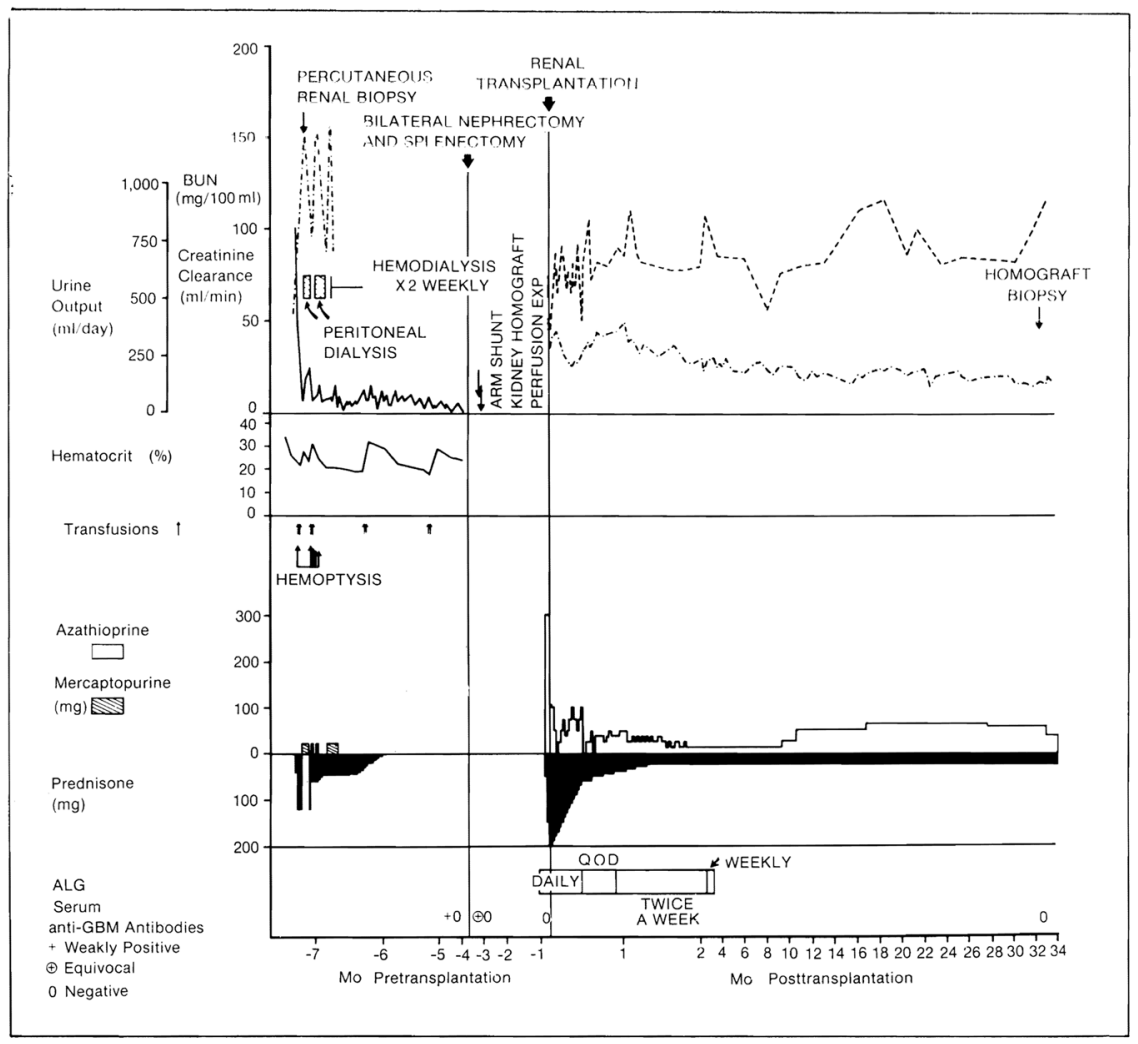

Fig 1.

Course of 30-year-old male patient (case 1). 


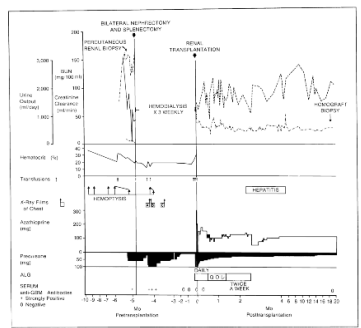

Fig 2.

Course of 29-year-old male patient (case 2). 


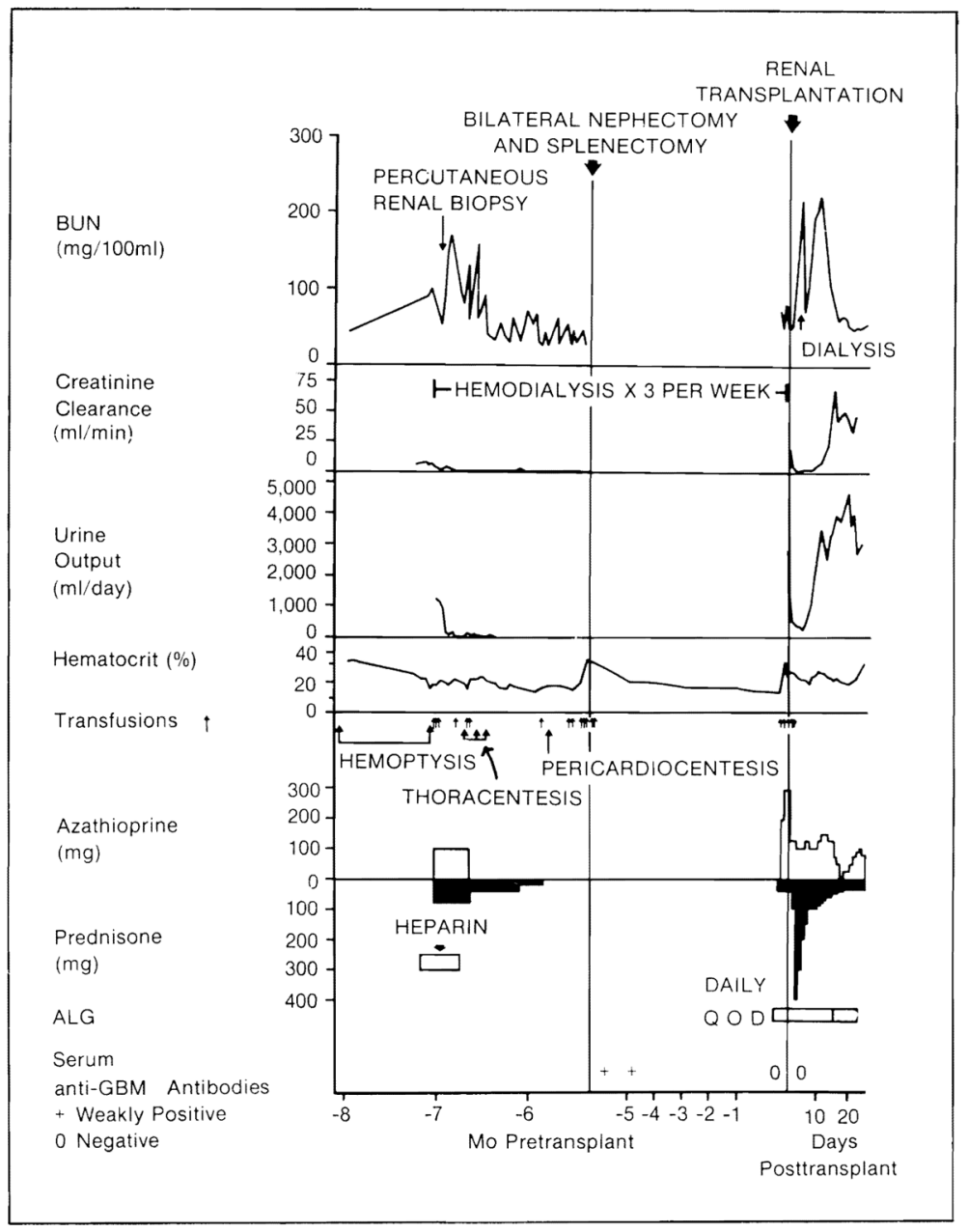

Fig 3.

Course of 35-year-old male patient (case 3) 

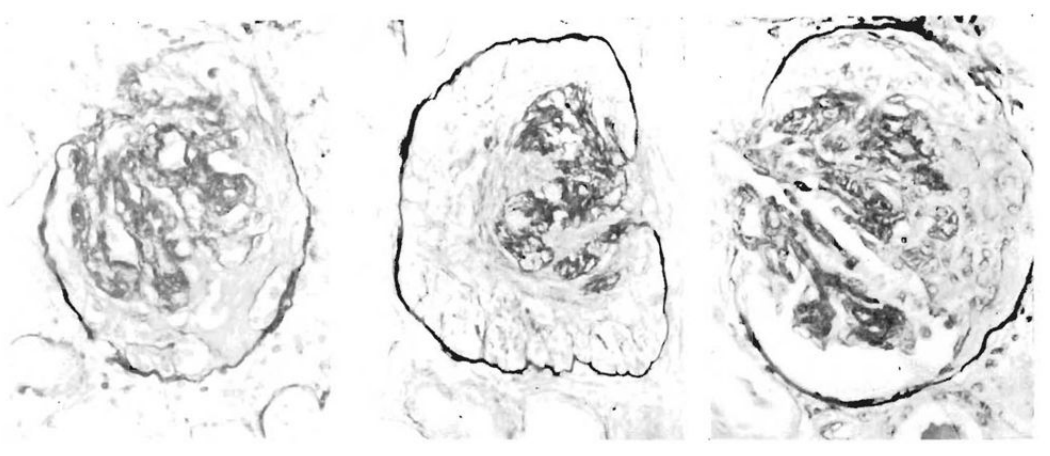

Fig 4.

Crescent forming subacute glomerulonephritis found in native kidneys of patients in case 1 (lett), case 2 (center), and case 3 (right) (PAS, $\times 340$ ). 

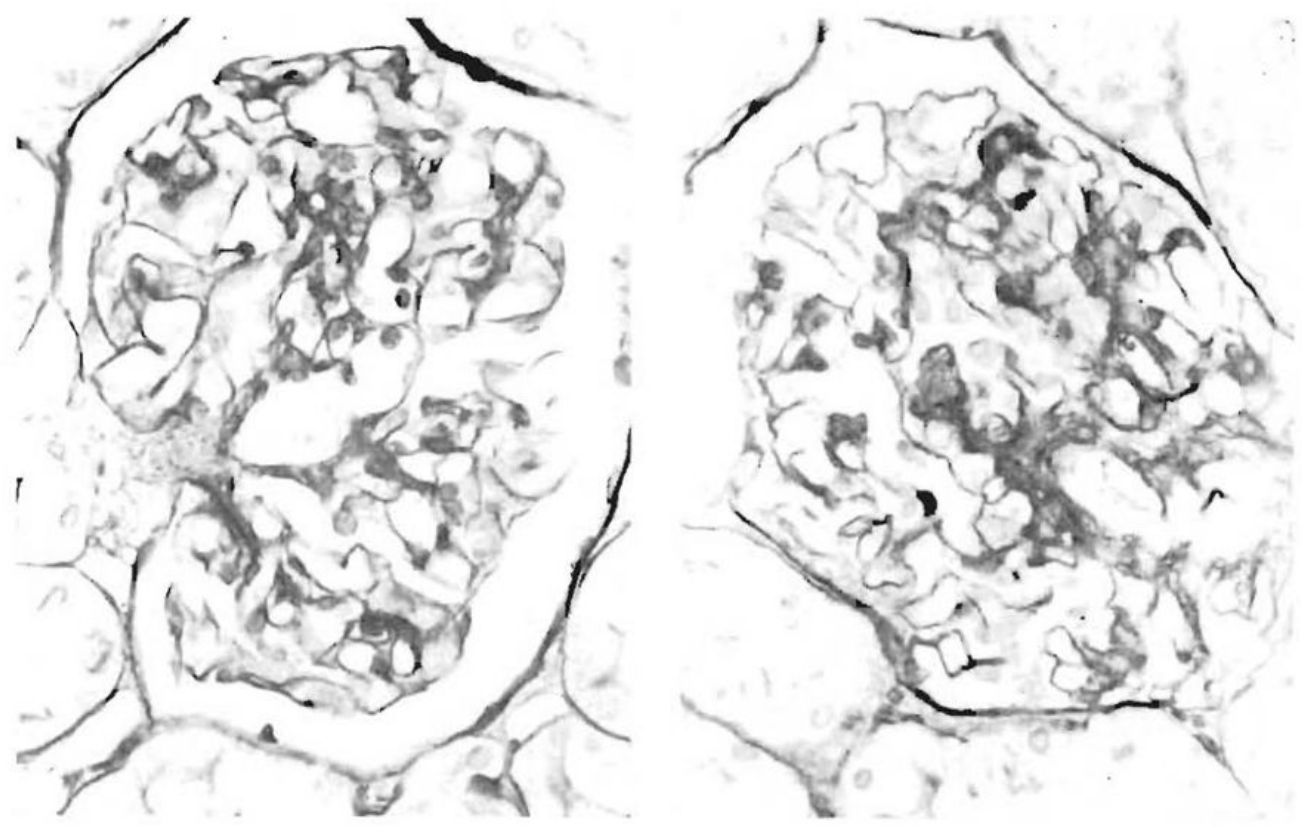

Fig 5.

Normal histologic appearance of representative glomeruli from renal homograft biopsies of case 1 (left) 34 months posttransplantation and case 2 (right) 20 months posttransplantation (PAS, $\times 340)$. 


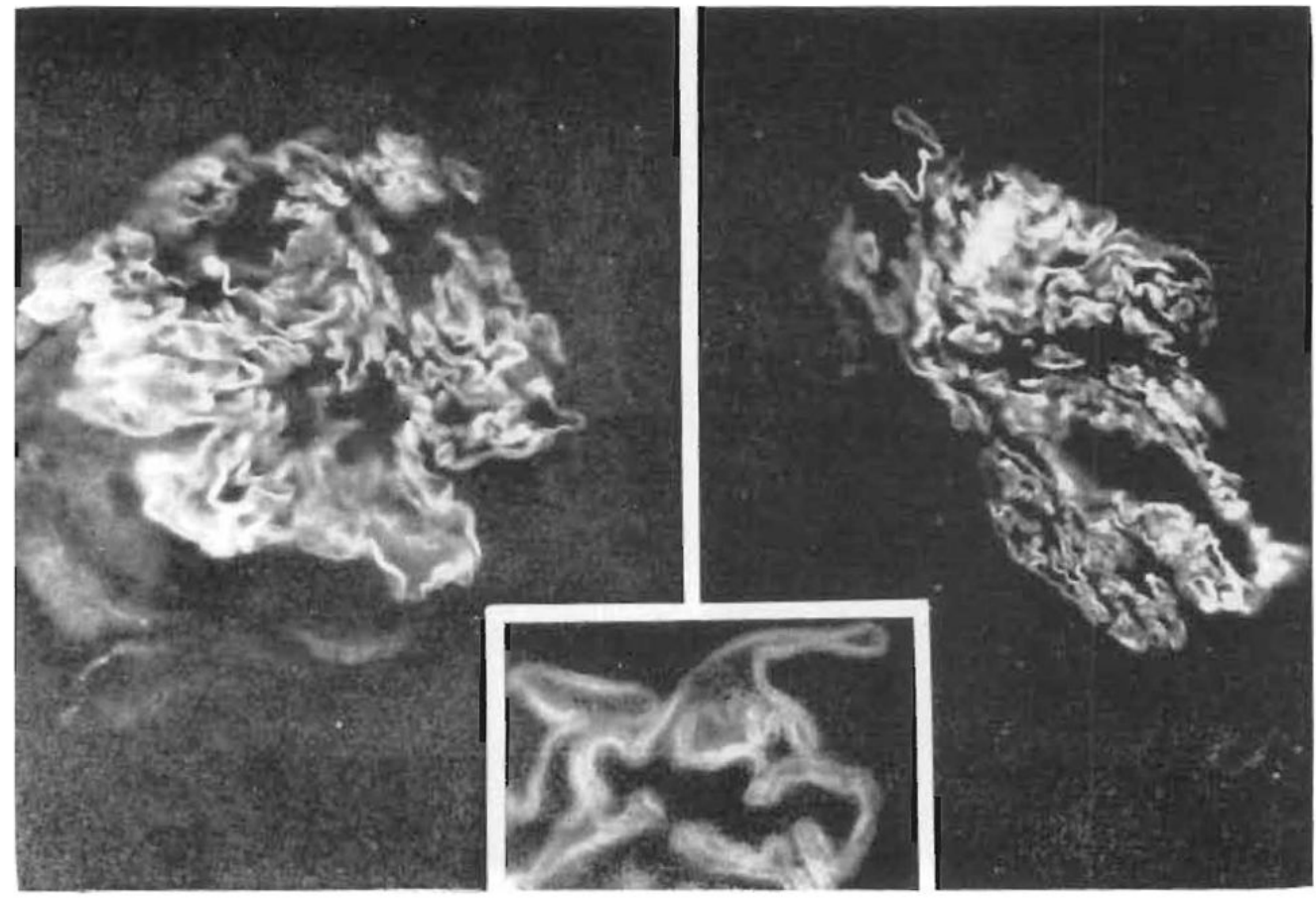

Fig 6.

Smooth continuous linear deposits of human $\mathrm{IgG}$ found along glomerular basement membrane (case 2) (fluorescein isothiocyanate-conjugated rabbit anti-human $\operatorname{IgG}, \times 250$; inset, $\times 1,000$ ). 


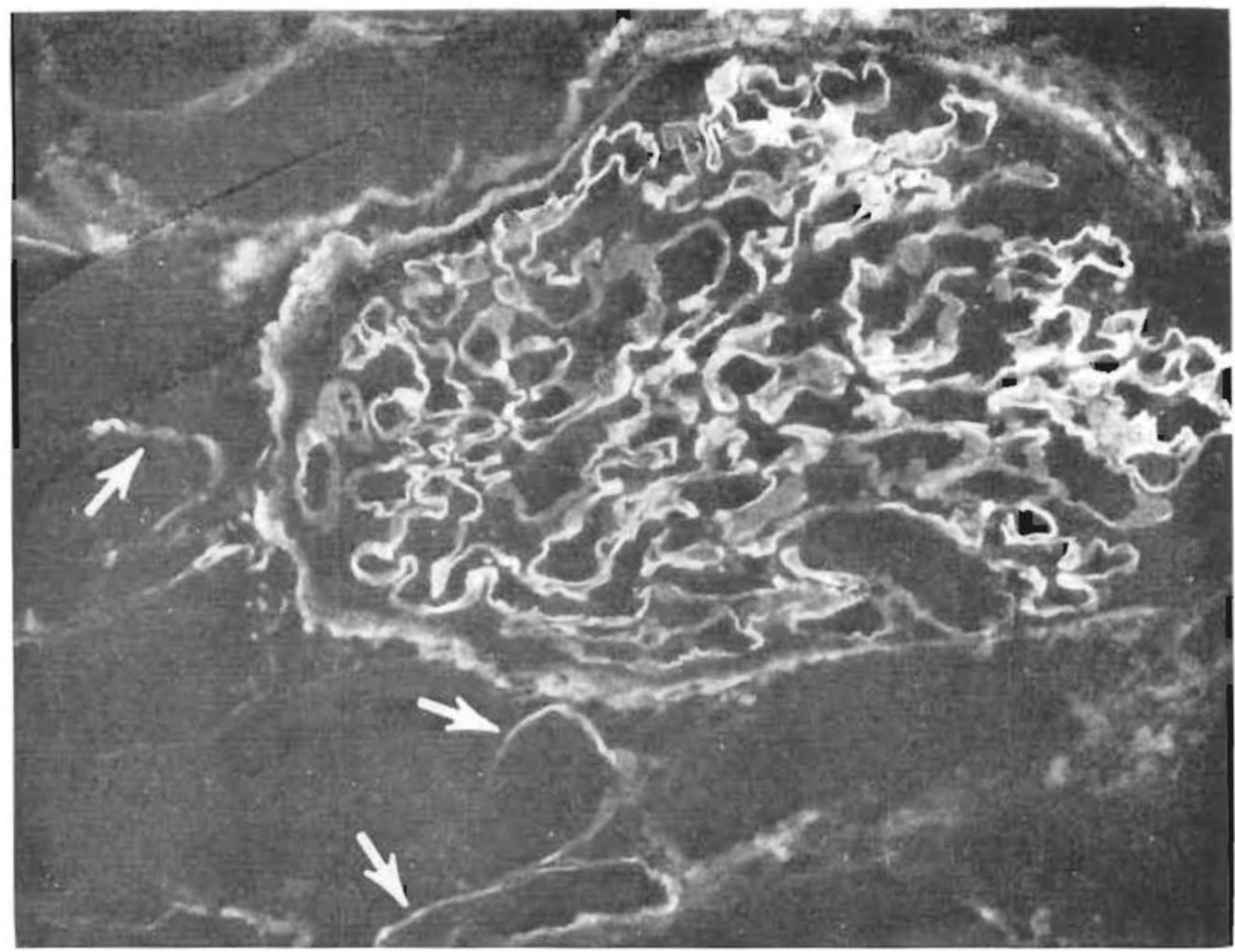

Fig 7.

Fixation of human IgG eluted ( $\mathrm{pH}$ 3.2) from native kidney to normal human kidney section (case 2). Fixation is to glomerular basement membrane, Bowman's capsule, and to tubular basement membranes (arrows) (fluorescein isothiocyanate-conjugated rabbit anti-human IgG, $\times 250)$. 


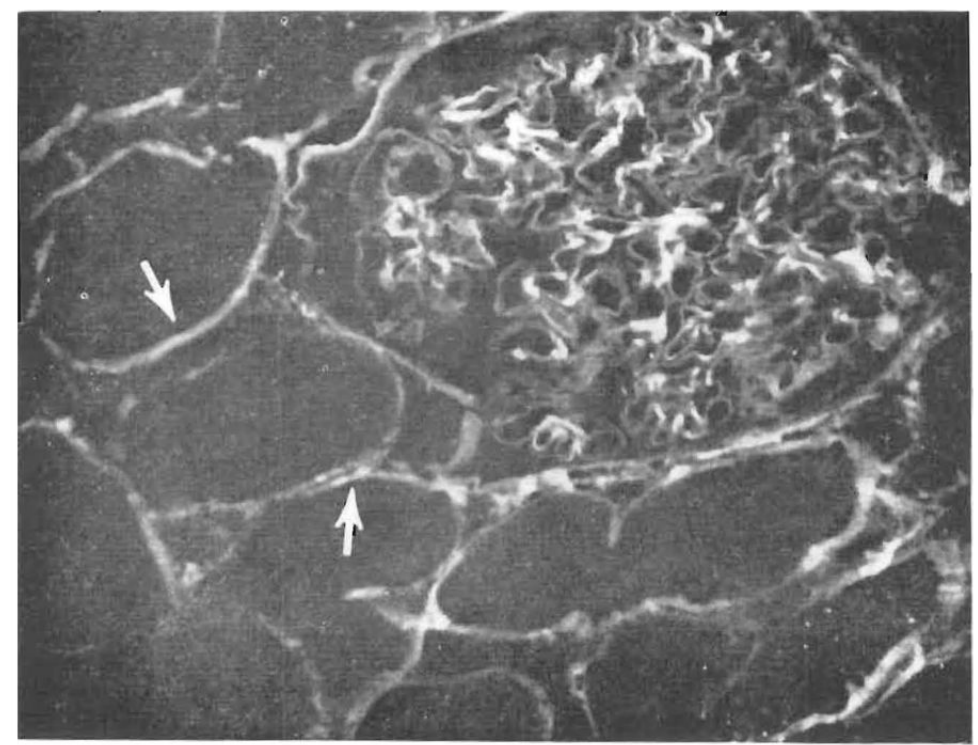

Fig 8.

Fixation of $\mathrm{IgG}$ from immediate postnephrectomy serum of to a normal human kidney section (case 2). Fixation is to glomerular basement membrane, Bowman's capsule, and tubular basement membranes (arrows) (fluorescein isothiocyanate-conjugated rabbit anti-human IgG, $\times 250)$. 

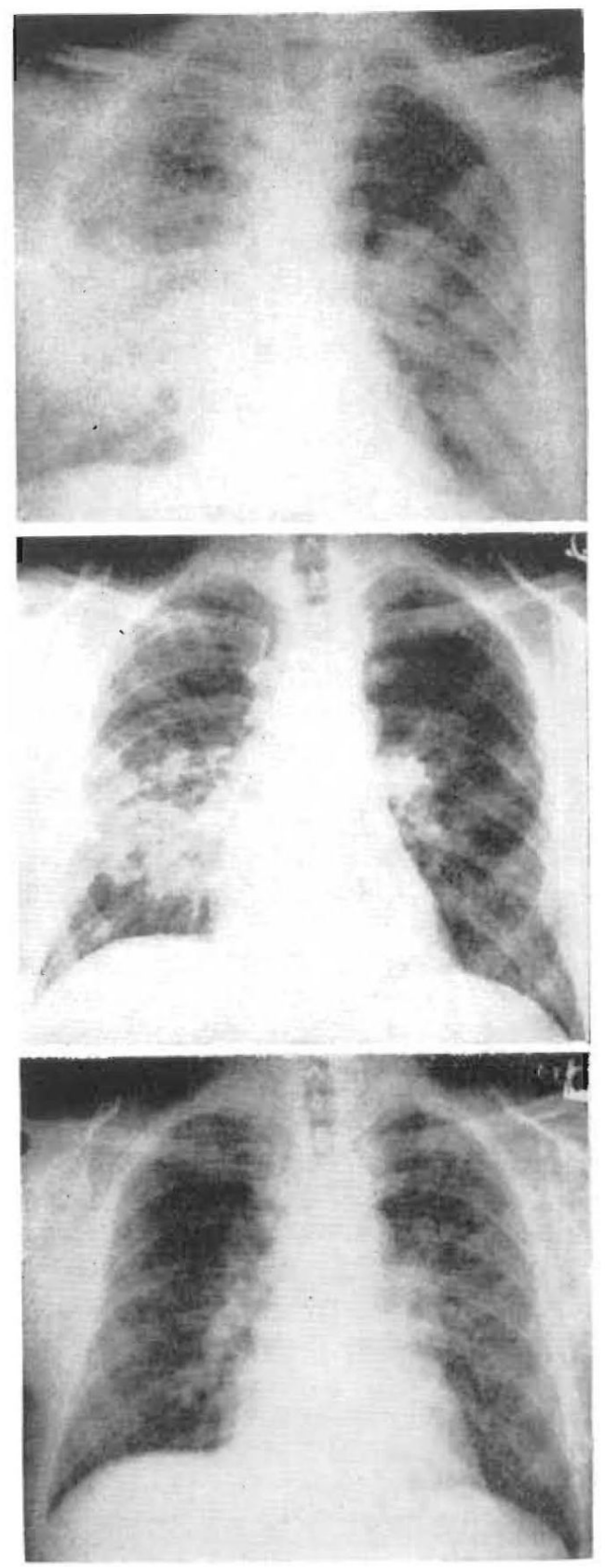

Fig 9.

X-ray films of the chest 19,21, and 41 days following bilateral nephrectomy and splenectomy. Diffuse pulmonary infiltrate (top) was associated with massive hemoptysis and severe alveolar-capillary diffusion defect. Two days later, after increase in dosage of prednisone the hemoptysis diminished, diffusion block improved, and infiltrate began to clear (center). Twenty days later, $\mathrm{x}$-ray film was normal (bottom) and patient was asymptomatic (case 2). 


\section{Table}

Case Material

\begin{tabular}{llll}
\hline & Case 1 & Case 2 & Case 3 \\
\hline Date of onset & $10 / 1 / 67$ & $9 / 13 / 68$ & $5 / 29 / 70$ \\
\hline Age of patient, yr & 30 & 29 & 35 \\
\hline Date of splenectomy and nephrectomies & $1 / 24 / 68$ & $2 / 4 / 69$ & $8 / 19 / 70$ \\
\hline Date of transplantation & $4 / 29 / 68$ & $7 / 3 / 69$ & $1 / 28 / 71$ \\
\hline Kidney donor & Brother & Brother & Sister \\
\hline Terasaki match & $\mathrm{A}$ & $\mathrm{A}$ & $\mathrm{D}$ \\
\hline Time of posttransplantation, mo & 34 & 20 & \\
\hline
\end{tabular}

